\title{
MORTARS AND PLASTERS PRODUCED WITH EARTH-BASED SUSTAINABLE MIXES: A METHODOLOGY PROPOSAL FOR RECOVERY OF VERNACULAR ARCHITECTURE IN ROERO, PIEDMONT (ITALY)
}

\author{
M. Vignola ${ }^{1}$, D. Bosia $^{2}$, R. Pennacchio ${ }^{2, *}$, M. Zerbinatti ${ }^{3}$ \\ ${ }^{1}$ Politecnico di Torino, Viale Mattioli 39, Torino, Italy - marco.vignola94@ virgilio.it \\ ${ }^{2}$ Dept. of Architecture and Design, Politecnico di Torino, Viale Mattioli 39, Torino, Italy - roberto.pennacchio@polito.it \\ ${ }^{3}$ Dept. of Structural, Geotechnical and Building Engineering, Politecnico di Torino, Corso Duca degli Abruzzi 24, Torino, Italy - \\ marco.zerbinatti@polito.it
}

Commission II - WG II/8

KEY WORDS: Earth-based mortars, Roero, Restoration, Raw materials, Special waste

\begin{abstract}
:
The work presented is the achievement of a master degree project, developed at Politecnico di Torino. The paper aims to provide standards for the formulation and mixing of earth-based mortars, for the rehabilitation of historic buildings of the Roero area, in Piemonte region. Roero presents a large architectural heritage, consisting mainly of fired or earth bricks rural and residential buildings, which was anciently protected using lime or earth-based plasters perfectly integrated with local landscape and environment colours appearance. In recent decades (and still to present days), vernacular plasters are frequently replaced by cementbased products, resulting hardly compatible with local bearing walls materials and landscape aesthetic features. While Roero traditional buildings plasters were produced using local earth and sands coming from streams, today, aggregates extraction in watercourses proximity is not allowed, or strictly regulated by rules and regional regulations. The paper presents a classification of the characteristics of different soils from Roero area, through different types of particle distribution size analysis and diffractometric tests, and propose a method for the production of local earth-based plasters stabilized with lime, making use of earth and rocks from local excavation sites, considered in Italy as secondary raw materials or special waste. Produced plasters compressive and bending strength have been tested, while their suitability for building maintenance and restoration, as their compatibility with Roero architecture and landscape, have been verified through spectrophotometric measures.
\end{abstract}

\section{INTRODUCTION}

\subsection{Research aims}

The paper's aim is to resume the ancient technology of earthbased mortars for plasters used in Roero and to introduce organic mortars for sustainable local architecture, suitable to be applied also in restoration field. Parameters for the choice of materials, mixtures formulation procedures, have been defined through an experimental methodology, developed during a Master Degree Thesis at Politecnico di Torino.

\subsection{Area framework and traditional Architecture}

Roero is a geographic area located in the south-west Piedmont, with a hilly morphological profile, dating back to the Pliocene and Miocene era. Regional landscape and architecture richness are the result of combined action of nature and man. Traditional small towns and villages perched on the hills were built by local population with different technologies, mostly depending on the characteristics of building resources and materials available on site. Geologically, the area was formed by the combined action of Messinian deposits of an ancient drying up deep sea, quaternary deposits, released by Alps glaciers covering the area, and tectonic movements (Boano et al., 1992).

Resulting significant diversification of geomorphological traits in the area (Soletti et al., 1997) is shown in figure 1:
- The Villafranchian complex: river-glacial soils from the Quaternary period.

- The Fossanian lands: transition sector between the Villafranchian soils and the Astian Sand area.

- The Astian Sands: soils with silty-sandy features generated by sediments' deposit from a receded marshy sea.

- The Messinian and Tortonian lands: clay marls of marine origins.

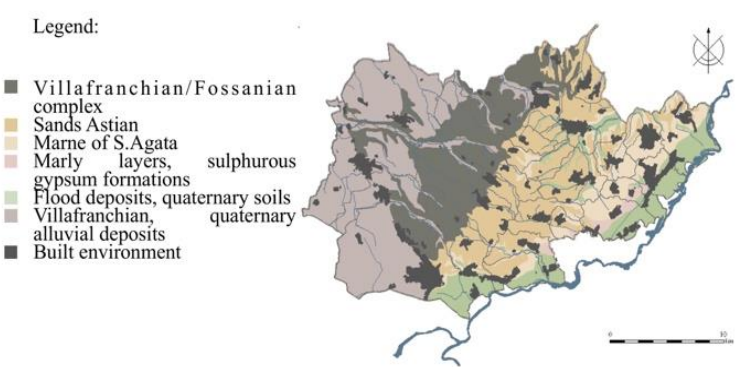

Figure 1. Geomorphological Map of Roero, reworked by the authors.

Moreover, the area is characterized by high gravelly and sandy cliffs, called "Rocche", separating the Fossanian land from the Astian Sands, and generated by the combined action of orogenic movements and erosion of an ancient river that changed its course. The presence of these high soils diversity determined the

\footnotetext{
* Corresponding author
} 
development of different building techniques that highly influenced local traditional architecture. Next to Tanaro river, to the south edge of the area, where soils are rich in calcium and gypsum, coursed stone and brick masonry building techniques result the most widely used. There were no stone quarries in the area and earth was the only available material in large quantities, so local people learnt to use the different types of soil as a building material (Accigliaro, 2009). In north and north-west Roero, where soils are rich in iron oxides, terracotta bricks are the most common material used for loadbearing walls structures. Lastly, in south and south-east part of the area, raw earth bricks or adobe (Houben, Guillaud, 1994) were the most used masonry technologies, as earth was the cheapest raw material available nearby. Houses were built on stone foundations, while walls were made from Roero clay soil (Soletti et al., 1997) and then plastered, using the same material. Literature data report how most common mortars for plasters were produced from local lime, gypsum and raw earth (Soletti, 1984). From ancient gypsum quarries, situated in south-eastern Roero, was extracted the material for the production of mortars used as stucco and for the construction of false ceilings (Soletti et al., 1997). Masonry findings, kept in local museums, show the use of lime mortars, made from local soil limestone, mainly used in the north-west part of the area. In the southern part of the region, where adobe building technology was most widespread, earth was used as a binding material for the production of earth-based mortars.

During the Middle Ages, rustic architecture bricks masonry was frequently left exposed, while in the Renaissance period, particularly the aristocratic buildings acquired refined architectural details, realized with lime plasters (Soletti et al., 1997). As a consequence, rural world was influenced by this trend, spread by the aristocracy; but due to the poor average incomes, earth plaster technology was widely employed. Earth-based plasters were used particularly in the southern part of Roero, where soil has marine origins. On the contrary, lime plasters made with local streams sands were widely used in the northern part of the region. Still today, many of those buildings preserve the original covering (Figure 2), presenting, in certain cases, rough surfaces showing its components natural colours, or, in other cases, smoother surfaces dyed with lime and colouring (Molino, 1997). Since the end of 19th century and during 20th century, those natural plaster techniques were replaced by cement binders, widely used until today, both in modern and contemporary architecture, both in the restoration of ancient buildings. Traditional mortars where gradually abandoned and today, only few craftsmen still hold the knowledge needed for its production and application. As a consequence, cement-based mortars and plasters have shown several negative side effects over the time.
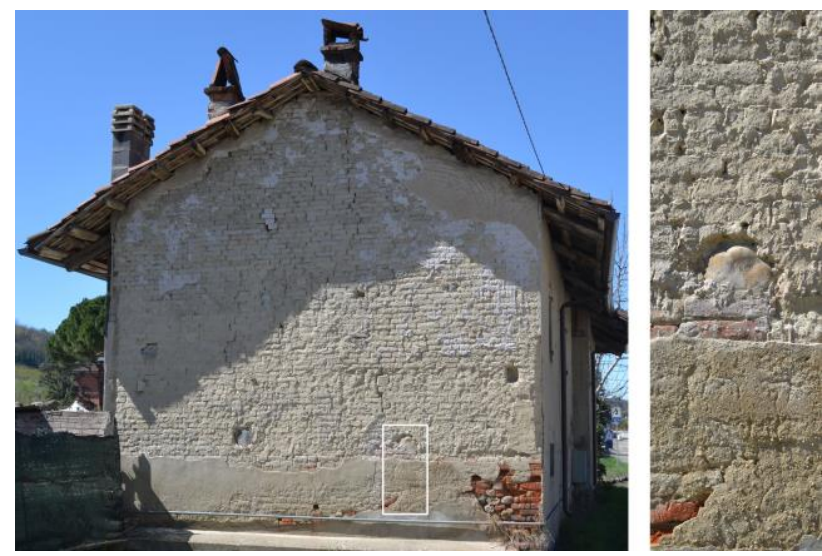

Figure 2. Earth plasters on adobe walls, Photo by the authors.
The wide use of cement plasters and unnatural paints in architecture, during the last decades, caused relevant alterations in the landscape and built environment perception. The topic is gaining more and more attention recently in research field, in Italy and particularly in Roero area, as it is being interested by major investments, highly linked to the conservation and development of its landscape and built environment, as to the recovery of local cultural traditions (Marchiano et al., 2019).

This research proposes a methodology for the production of mortars, suitable to be employed for the protection of local traditional architecture and relying on the analysis of Roero traditional clayey and lime mortars, that intends to answer the need for sustainable mixtures and materials, alternative to cement-based plasters (Melià, 2013).

Large attention has been paid, recently in Europe, to the production of natural plasters, suitable for earth buildings rehabilitation and conservation (Faria et al., 2013), also involving local artisans, still holding ancient techniques knowledge (Harmard et al., 2011; El Ghezzali, 2015; Contreras, Baca, 2007). Nevertheless, no specific studies have been found concerning traditional mortars used in Roero.

A historical reconstruction of local traditional mortars evolution was conducted through the work of Accigliaro (2009), Molino (1997) and Soletti (1984). The collaboration with the local company F.lli Sartore s.r.l. helped to resume the ancient local techniques, now out of trade, and to develop an accessible earth mortars production methodology for local enterprises.

\section{EXPERIMENTAL METHODOLOGY}

The research program has been organized in four principal phases. First two phases have analytical purpose and have been oriented to define a method for the selection of suitable raw materials, locally available. Last two phases have been dedicated to the definition of correct mortar mixtures ratios and to the characterization of the produced mortars.

Phase 1 allowed to map needed local raw materials availability, such as earth and sand; to define a method for the selection of a wide range of suitable soils for earth-based mortars, collecting soil samples from different areas in the region, showing different morphological and lithological typologies. Six different soils samples have been selected, to be analysed and used for mortars production.

A sustainable procedure for materials extraction has been also assessed, according to national D.M. 162/2006, which refers to excavated soils and rocks waste recovery.

Phase 2 Selected soils grain size distribution analysis has been assessed to verify their suitability for earth-based mortars. Two different analysis methods, UNI-ASTM (UNI EN 933, 1999; ASTM D422-63, 2007) and Agronomic method (D.M., 1999), have been tested, so to grant an affordable procedure to the construction companies working in the field.

Phase 3 Starting from selected samples grain size distribution analysis, an experimental method, based on Italian and European regulations, has been applied, so to define the correct ratio of the stabilized mortars components. As a result, clay content has been adjusted, and the volume of stabilizing material to add to earth-sand mixture has been calculated. 
Phase 4 Produced mortars were characterized through laboratory tests, to assess materials mineralogical composition, dynamic elastic modulus $\left(\mathrm{E}_{\mathrm{d}}\right)$, mortars colorimetric variations, compressive and bending strength.

\section{RAW MATERIALS SELECTION AND ANALYSIS}

\subsection{Raw materials availability and selection}

Starting from the analysis of the Provincial cartography and the Piedmont Region regulations, the features of the area were studied and mapped, representing all types of soil distribution and the presence of active quarries in the Roero area. Earth and sand come from active local quarries, while lime comes from the closest furnace "Calce Piasco", located in the municipality of Piasco (Cuneo Province). Local materials use is regimented by regional regulation and subject to certain landscape constraints (Quaglia et al., 2005). The consultation of the mining database of Piedmont Region, allows to map all local active quarries, for sands extraction. There are no active quarries for the extraction of earth or clay in this area. In addition, soil consumption is considered as a main critical aspect to deal with (COM 231, 2006). As a consequence, current Italian regulation allows the use of excavated soils and rocks, as a substitute for quarry materials, to reduce mining activity (D. Lgs 152, 2006), in the attempt of limiting resource consumption and soil erosion. Italian law defines soils from excavation activities as a waste to be disposed of, in specialized landfills. But it also introduces the concept of by-product, whereby, once checked through chemical analysis, these soils can be introduced in new production cycles, as a secondary raw material, to reduce the extraction activity.

According to the Article 184-ter, recovered soil can be reused in different ways, such as material for construction sites or as secondary raw materials in new production processes (D. Lgs 152, 2006). All construction sites, producing excavated material, generate waste soil, that can be so used as a byproduct and reused as secondary material.

Taking advantage of this opportunity, criteria were defined, in order to set up a case study in the Roero area (Vignola, 2019), allowing to evaluate and map the different types of soils available in the area. The case study defined according to the geomorphological landscape features of this territory (Quaglia G. et al., 2005), includes six municipalities: Ceresole d'Alba, Baldissero d'Alba, Sommariva Perno, Corneliano d'Alba, Monticello d'Alba e Santa Vittoria d'Alba (Figure 3).
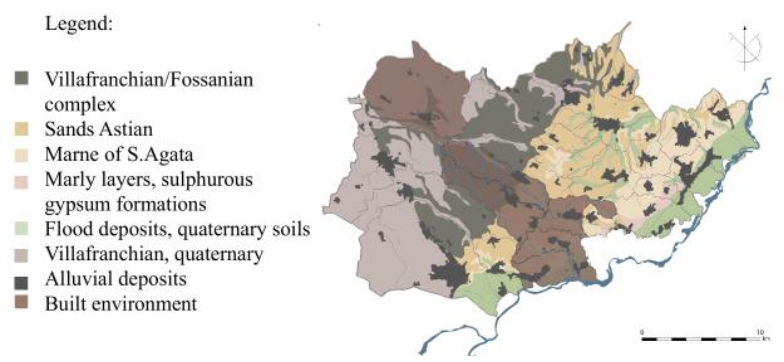

Figure 3. Study Area, Geomorphological Map, reworking of the authors.

The land is divided in zones with different soil types, represented as parallel layers with common features. The villages selected for the study allows to consider all the sediments available in Roero area. Samples were taken all over the six municipalities, particularly from lands earmarked for new buildings construction.
Samples coming from the same district have been collected from two different lots of land, as the soil of a hamlet has the same morphological and lithological typology, while it can change from hamlet to hamlet for geomorphological aspects. In addition, each soil sample comes from the mixing of two samplings, carried out in the same site, as the same soil sediment may have different shades and characteristics. The twelve gathered soil samples were classified with a code, corresponding to the town of origin and a number; the BA1 case is an example of the study done on village grounds (Figure 4). Six of the twelve earths samples were chosen to be analyzed, due to their high colorimetric and granulometric differences, getting the following code: CE2, BA1, SP1, CO2, MO2, SV1 (Figure 5).

\section{P.R.G. -BALDISSERO D'ALBA}

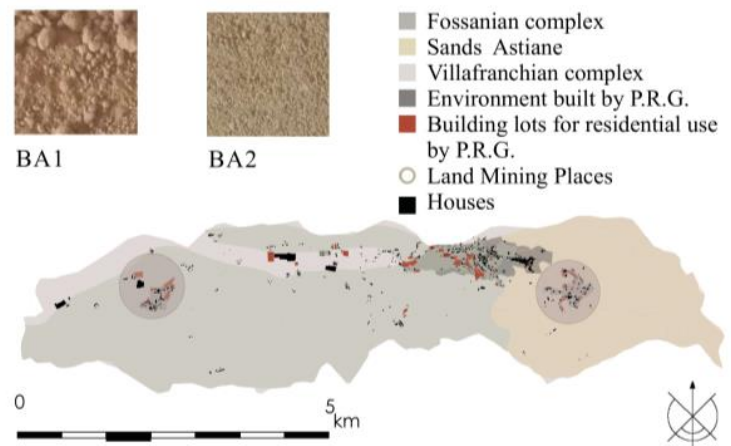

Figure 4. Taken earths, reworking of the authors.

Samples, belonging to the Villafranchian, Fossanian geological complex and Astian sands, are coded as CE2, BA1 and SP1, respectively, while samples with code $\mathrm{MO} 2, \mathrm{SV} 1$ and $\mathrm{CO} 2$ are associated respectively to the Messinian complex, and the Tortonian complex.

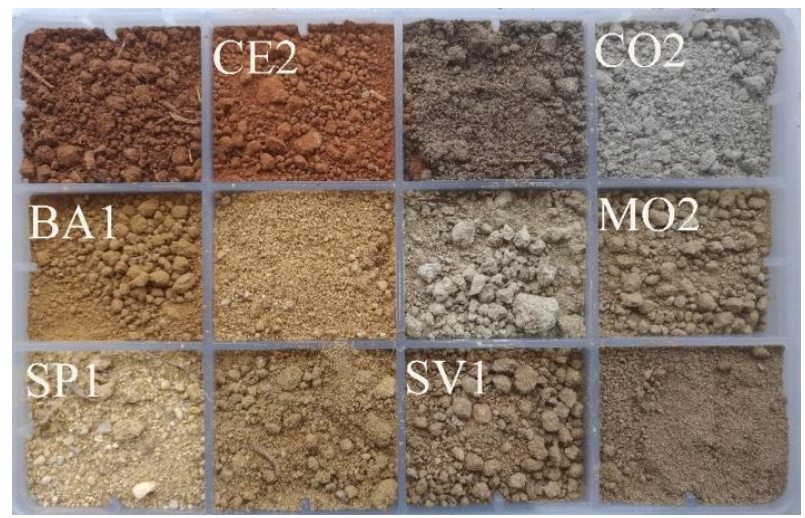

Figure 5. Taken earths, author's photo.

\subsection{Earth-sand mixtures grain size distribution analysis}

Mortars for plaster are made up of grains smaller than $4 \mathrm{~mm}$, sand fraction $4-0,063 \mathrm{~mm}$, silts $0,063-0,002 \mathrm{~mm}$, while the grains smaller than $0,002 \mathrm{~mm}$ constitute the clay part, behaving as a binder (Pecchioni, 2008).

According to Briccoli Bati S. (2010) and Scudo (2001), clay mass, contained in an earth-based mortar, should be between 5 and $12 \%$. Smaller quantity doesn't ensure enough bonding power, while a larger quantity could cause excessive shrinkage and consequent cracks, during the drying process. So, to reduce the clay content in the mixture, certain quantity of sand is added. Formulated mortars show $9 \%$ clay content into the sandearth mass of the mixture. 
With the aim of proposing a grain size distribution analysis method, affordable by local companies, two different procedures, oriented to define retrieved earth-sand samples clay content, were compared: UNI-ASTM method (UNI EN 9331:1999; UNI EN 933-1, 2012; CNR BU23/71; ASTM D422-63) and an agronomic method (D.M. 13/09, 2009). The last method provides rules for a wet sifting procedure, allowing to define a simplified grain size distribution curve, by determining gross sand, silt and clay content, with similar results to UNI-ASTM method. This was considered advantageous, precisely because it has already been used by various laboratories in the region, at affordable prices.

Six samples grain size distribution analysis, following the UNIASTM method, was carried out at DISEG laboratory of Politecnico di Torino, (UNI EN ISO 14688-1, 2003; UNI EN 932-2, 2000; UNI EN 933-1,1999; UNI EN 933-1,2012; ASTM D422-63, 2007). Figure 6 shows Ceresole d'Alba soil particle size curve, coded CE2.

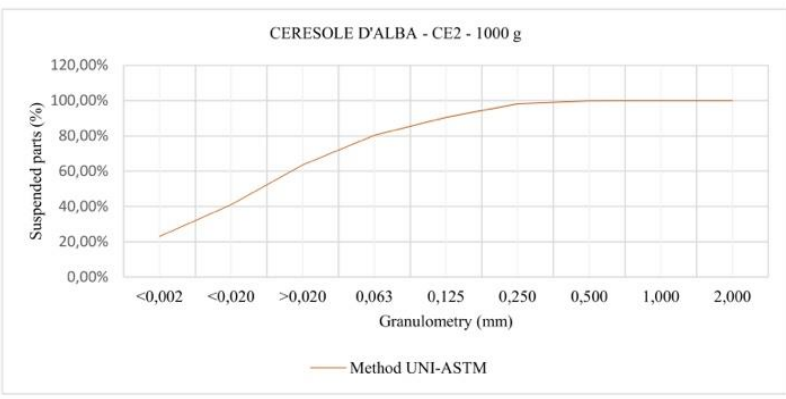

Figure 6. Selected soils grain size distribution - Method UNIASTM, reworking of the authors.

The agronomic method grain size distribution analysis, carried out through sedimentation field tests at the "Cascina la Pranda" and, through wet sieving (D.M 13/09, 1999), at Enocontrol laboratory (Alba, CN), led to six samples grain size distribution curve tracking. Field studies, to define gross soils samples features were previously realized (Achenza, Sanna, 2009; Pennacchio, 2015)

UNI-ASTM method provides more accurate data, due to the greater amount of information about grain-size classes ( 9 versus 5 , respectively), but agronomic method provides anyway exhaustive data, to evaluate the clay content within the soil mass.

As to directly compare the results of both methods, UNI-ASTM grain size distribution curve was reduced to five grain size classes. Figure 7 reporting Ceresole d'Alba soil curves (CE2 code) shows how proposed methods produced quite similar results, regarding clay content.

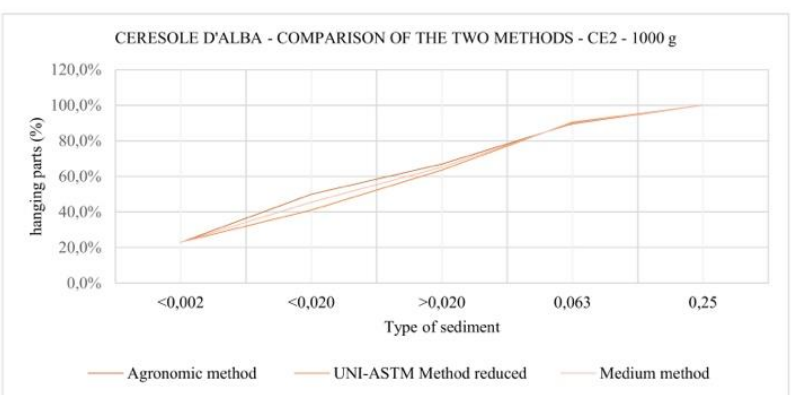

Figure 7. Selected soils grain size distribution - Comparison method, reworking of the authors.
Sieves mesh size, used in both methods, produces certain results discrepancy. UNI-ASTM method considers as sand the part of soil with grain size $0,250-0,063 \mathrm{~mm}$, while in agronomic method, sand shows $0,2-0,05 \mathrm{~mm}$ grain size, which leads to $18 \%$ discrepancy among the two methods results. Silt and clay content, determined by ASTM D422-63 and D.M. 13/09 procedures respectively, lead to $9 \%$ discrepancy in case of silt content and $0,5 \%$ discrepancy in case of clay content, showing agronomic clay content estimation as a reliable data. Considered average grain size distribution curves gave the following results:

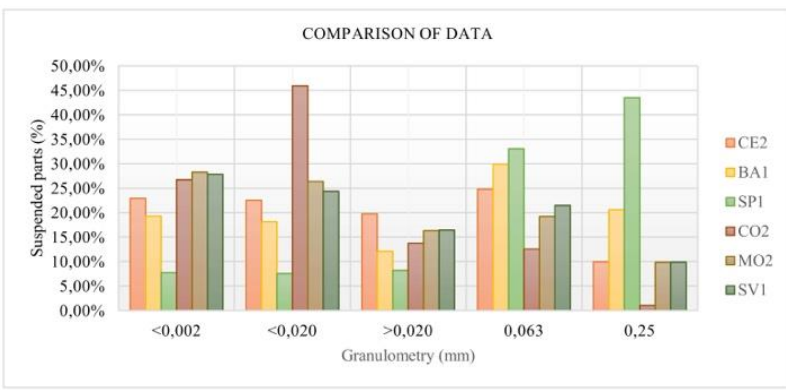

Figure 8. Roero soils grain size distribution comparison Data, reworking of the authors.

Villafranchian (EC2) and Fossanian soils (BA1), 22\% clay, $45 \%$ silt, $33 \%$ sand, and $20 \%$ clay, $30 \%$ silt, $50 \%$ sand respectively, show loamy-clay and clay composition. Tortonian samples (CO2) show $26 \%$ clay, $64 \%$ silt and $10 \%$ sand loamy soils, Messinian clay soils (MO2, SV1) show $28 \%$ clay, $45 \%$ silt and $27 \%$ sand, while Astian sand (SP1), $8 \%$ clay, $16 \%$ silt and $76 \%$ sand, are considered sandy soils (Figure 8).

Soils CE2, BA1, CO2, MO2 and SV1 show quite high clay content, exceeding $20 \%$, and need to be slim down for plaster mortars use (Scudo et al., 2001), because the high presence of phyllosilicates increases the shrinkage phenomena, during the drying phase. Consequently, it is necessary to balance the aggregates curve, to reduce the volume of the voids and so the quantity of clay.

\section{EARTH-BASED MORTARS PRODUCTION AND CHARACTERIZATION}

\subsection{Methodology for the production of earth plasters stabilized with lime}

Six earth-based mortars, stabilized with lime, were produced from soil samples retrieved in Roero, following a methodology adopted in previous studies carried out at the Polytechnic of Turin (Giuria, 2018; Vecchio, 2019; Zerbinatti, 1998). A further mortar was obtained by lime and sand only, and was used as a standard, to be compared with the six earth-based mortars produced. The dosage study of mortar components has been organized in three main phases:

Phase 1: Earth mixtures clay content decrease (Giuria, 2018); Phase 2: Determining Bulk density (Vecchio, 2019);

Phase 3: Determining the volume of voids (Zerbinatti, 1998).

Once known mixtures bulk density and volume of voids, the correct volume of lime, to be added to the mortars, was defined. 
4.1.1 Earth-sand mixtures decrease in clay content: Mixtures clay content have been decreased down to the $9 \%$, with the addiction of sand. The needed amount has been calculated by setting the following inverse proportion (1):

$X t: X t, t o t=X s t, t o t: X s t$

Where:Xt: Clay content in the soil mass, Xt,tot: Total earth mass, Xst,tot: Total earth/sand mass, Xst: $9 \%$ of clay

\begin{tabular}{|l|c|c|c|c|c|}
\hline Code & Clay & $\begin{array}{c}\text { Earth } \\
\text { mass }\end{array}$ & $\begin{array}{c}\text { Clay } \\
9 \%\end{array}$ & $\begin{array}{c}\text { Tot. Earth } \\
\text { mass }\end{array}$ & $\begin{array}{c}\text { Sand } \\
\text { addition }\end{array}$ \\
\hline & $(\%)$ & $(\%)$ & $(\mathrm{g})$ & $(\mathrm{g})$ & $(\mathrm{g})$ \\
\hline CE2 & 22,94 & 100,00 & 9,00 & 254,89 & 154,89 \\
\hline BA1 & 19,30 & 100,00 & 9,00 & 214,44 & 114,44 \\
\hline SP1 & 7,73 & 100,00 & 7,73 & 100,00 & 0,00 \\
\hline CO2 & 26,75 & 100,00 & 9,00 & 297,22 & 197,22 \\
\hline MO2 & 28,37 & 100,00 & 9,00 & 315,22 & 215,22 \\
\hline SV1 & 27,84 & 100,00 & 9,00 & 309,33 & 209,33 \\
\hline
\end{tabular}

Table 1. Addition of sand needed each $100 \mathrm{~g}$ of earth, produced by authors

Due to their high clay content, all soil samples needed consistent sand addition, except Astian sands soil, to which no sand was added, as soils sampled only contained $7.73 \%$ of clay, while, particularly to Messinian and Tortonian soils, about $200 \%$ sand addition was needed. Results are shown in table 1. Decreased clay content samples are marked with previous soil code followed by number 9 (CE2.9, BA1.9, SP1.9, CO2.9, MO2.9, SV1.9).

4.1.2 Determining Bulk density: Samples bulk density was calculated using the following formula (2):

$\rho_{\text {material }}=V_{\text {material }} / m_{\text {material }}$

where: $\rho_{\text {material }}$ : apparent density, $V_{\text {material }}$ : known volume, $m_{\text {material }}$ : weight of known volume

Each soil calculated density is the average value resulting from three different soil samples. $m$ value was calculated through 4 weight measures of $130 \mathrm{~cm}^{3}$ sample volume, as shown in table 2. Different earth mixtures bulk density resulted quite homogeneous and in line with values shown by CE2.9 sample.

\begin{tabular}{|l|l|c|c|c|c|c|c|}
\hline Sample & Tare & Vol. & $\begin{array}{c}\text { Meas. } \\
1\end{array}$ & $\begin{array}{c}\text { Meas. } \\
2\end{array}$ & $\begin{array}{c}\text { Meas. } \\
3\end{array}$ & $\begin{array}{c}\text { Meas. } \\
4\end{array}$ & $\begin{array}{c}\text { Bulk } \\
\text { Density }\end{array}$ \\
\hline & $(\mathrm{g})$ & $\left(\mathrm{cm}^{3}\right)$ & $(\mathrm{g})$ & $(\mathrm{g})$ & $(\mathrm{g})$ & $(\mathrm{g})$ & $\left(\mathrm{g} / \mathrm{cm}^{2}\right)$ \\
\hline $\mathrm{N}^{\circ} 1$ & 59,44 & 130,0 & 158,83 & 159,61 & 160,52 & 160,09 & 1,23 \\
\hline $\mathrm{N}^{\circ}$ & 59,44 & 130,0 & 160,53 & 160,88 & 161,11 & 161,03 & 1,24 \\
\hline $\mathrm{N}^{\circ} 3$ & 59,44 & 130,0 & 160,33 & 160,74 & 161,07 & 161,14 & 1,24 \\
\hline $\begin{array}{l}\text { Av. } \\
\text { value }\end{array}$ & 59,44 & 130,0 & 159,90 & 160,41 & 160,90 & 160,75 & 1,23 \\
\hline
\end{tabular}

Table 2. Bulk density of earth CE2.9, reworked by the authors

\subsubsection{Determining the volume of voids:}

Phase 3 (Zerbinatti, 1998)(CNR BU 65/78, 1978)(UNI EN 9322, 2000): Earth-based mortars have been stabilized with certain amount of lime fat, determined by calculating the volume of voids of earth mixtures (Zerbinatti, 1998).

Dry soil can be considered as a multiphase system, based on a skeleton of solid parts and a percentage of voids. This last percentage represents the quantity of stabilizing binder to add to the earth-sand mixture. Voids percentage calculation is related to the weight of a known volume, measured on the basis of a dry mass. Drops of water are then added, to obtain a workable paste, with moderate plasticity; $2 \mathrm{ml}$ of water are added at once (Zerbinatti, 1998), filling the voids inside the mixture. The percentage of the void index, weighting into the saturated mass, has been calculated through the formula (3):

$V_{v}=\left(\left(\rho_{s t}-\rho_{s e}\right) / \rho_{s t}\right) * 100$

Where: $V_{\mathrm{v}}$ : Percentage volume of voids, $\rho_{\mathrm{st}}$ : volume mass of saturated material, $\rho_{\mathrm{se}}$ : volume mass of dry material

Table 3 shows the calculation of CE2.9 mixture voids index. Mixture void index found have been then replaced by equal amounts of lime, expressed in parts of the volume. Approximately, 1 part of lime has been added for each 4.5 parts of CE2.9 mixture.

\begin{tabular}{|c|c|c|c|c|c|c|c|}
\hline $\begin{array}{c}\text { Sample } \\
\text { CE2.9 }\end{array}$ & M.1 & M.2 & M.3 & M.4 & $\begin{array}{c}\text { Bulk } \\
\text { Density }\end{array}$ & $\begin{array}{c}\text { Voids } \\
\text { vol. }\end{array}$ & $\begin{array}{c}\text { Binder } \\
\text { mixture } \\
\text { ratio }\end{array}$ \\
\hline & $(\mathrm{g})$ & $(\mathrm{g})$ & $(\mathrm{g})$ & $(\mathrm{g})$ & $\left(\mathrm{g} / \mathrm{cm}^{3}\right)$ & $(\%)$ & $($ parts $)$ \\
\hline Dry & 24,63 & 24,55 & 24,40 & 24,64 & 1,23 & & \\
\hline $\begin{array}{c}\text { Saturated } \\
\text { sample }\end{array}$ & 31,63 & 31,55 & 31,40 & 31,64 & 1,58 & 22,18 & 4,51 \\
\hline
\end{tabular}

Table 3. CE2.9 sample Earth Voids Index for $20 \mathrm{~cm} 3$ volume. Produced by the authors.

4.1.4 Mixture preparation: Once the volume of lime to be added to the mixture has been defined, multiplying the voids index found by the density of the earth-sand mixture (Zerbinatti, 1998), a percentage of water, $12 \%$ of the stabilized mixture weight (Vecchio, 2019; UNI 11201, 2007), was added. Straw fibres were also added, in the measure of $5 \%$ the volume of the stabilized mixture, to reduce shrinkage (Minke, 2000).

Table 4 shows the composition of $1 \mathrm{~kg}$ of prepared mortars, expressed in volumes.

Table 5 shows how produced stabilized mortars save significant amount of lime, if compared to a standard lime-based mortar.

\begin{tabular}{|c|c|c|c|c|c|}
\hline Mortar Code & Earth & Sand & Lime & Straw & Tot. \\
\hline & $\left(\mathrm{cm}^{3}\right)$ & $\left(\mathrm{cm}^{3}\right)$ & $\left(\mathrm{cm}^{3}\right)$ & $\left(\mathrm{cm}^{3}\right)$ & $\left(\mathrm{cm}^{3}\right)$ \\
\hline CE2.9 & 290,98 & 360,47 & 143,06 & 41,46 & 835,97 \\
\hline BA1.9 & 312,11 & 318,46 & 139,67 & 41,46 & 811,71 \\
\hline SP1.9 & 593,56 & 0,00 & 148,39 & 41,46 & 783,41 \\
\hline CO2.9 & 274,37 & 392,40 & 144,81 & 41,46 & 853,04 \\
\hline MO2.9 & 224,43 & 407,51 & 139,56 & 41,46 & 812,95 \\
\hline SV1.9 & 255,89 & 401,20 & 143,38 & 41,46 & 841,93 \\
\hline STR & 0,00 & 553,57 & 184,53 & 0,00 & 738,10 \\
\hline
\end{tabular}

Table 4. Mortars composition, in volume, for $1 \mathrm{~kg}$ material, produced by the authors.

\begin{tabular}{|c|c|c|c|c|c|}
\hline \multirow{2}{*}{$\begin{array}{c}\text { Mortar } \\
\text { Code }\end{array}$} & \multicolumn{2}{|c|}{$\begin{array}{c}\text { Comparison to } \\
\text { mortar STR }\left(\mathrm{cm}^{2}\right)\end{array}$} & \multicolumn{2}{c|}{$\begin{array}{c}\text { Comparison to } \\
\text { mortar STR (\%) }\end{array}$} \\
\cline { 2 - 6 } & & $\begin{array}{c}\text { Sand } \\
\text { decrease } \\
\left(\mathrm{cm}^{3}\right)\end{array}$ & $\begin{array}{c}\text { Lime } \\
\text { reduction } \\
\left(\mathrm{cm}^{3}\right)\end{array}$ & $\begin{array}{c}\text { Sand } \\
\text { decrease } \\
(\%)\end{array}$ & $\begin{array}{c}\text { Lime } \\
\text { reduction } \\
(\%)\end{array}$ \\
\hline CE2.9 & $-193,11$ & $-41,47$ & 42,51 & 31,55 \\
\hline BA1.9 & & $-235,11$ & $-44,86$ & 47,69 & 31,17 \\
\hline SP1.9 & & $-553,57$ & $-36,14$ & 100,00 & 24,23 \\
\hline CO2.9 & $-161,17$ & $-39,72$ & 38,67 & 32,10 \\
\hline MO2.9 & & $-146,06$ & $-44,97$ & 33,16 & 31,33 \\
\hline SV1.9 & & 152,37 & $-41,14$ & 36,46 & 31,88 \\
\hline
\end{tabular}

Table 5. Produced earth-based mortars volumes of sand and lime saved, if compared to a standard lime-based mortar (STR). Produced by the authors. 


\subsection{Prepared lime stabilized earth mortars characterization}

147 stabilized earth-based mortar samples, 21 each mortar type, were produced, and subjected to experimental tests, to characterize the obtained mortars. Produced mortars features were then compared with the lime-based mortar one and with data from analysis previously realized at Politecnico di Torino (Giuria, 2018; Vancetti, 2010; Vecchio, 2019). The following experimental tests were performed:

$X$-ray Diffractometry tests were performed to obtain used soils and sand mineralogical composition (UNI11305, 2009). Results showed two different types of soils: red soils and brown soils.

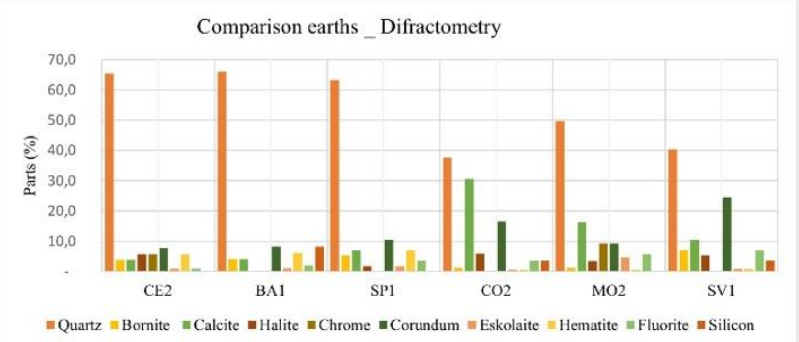

Figure 9. Comparison of earth's diffractometries, reworked by the authors

As shown in Figure 9, all the soils are mainly composed of silicon. High hematite content confers CE2, BA1, SP1 soils red colouring (red earths), brown soils $\mathrm{CO} 2, \mathrm{MO} 2, \mathrm{SV} 1$ show high lime and corundum content.

Ultrasound test (UNI EN 12504-4:2005) aimed at defining mortars dynamic modulus of elasticity. It was carried out on nine $4 \times 4 \times 16$ (UNI EN 1015-11, 2007) and nine 3x3x30 (Vancetti, 2010) format samples for each type of mortar. Results are shown in table 6.

All stabilized earth-based mortars show low elastic modulus. Similar results have been obtained from STR mortar analysis and data reported in Vecchio (2019). However, in order to have more reliable data for earth-based mortars stabilized with lime, deemed suitable for plastering the earthen walls, similar tests on a large number of samples would be needed.

\begin{tabular}{|c|c|c|c|c|c|c|c|c|}
\hline \multicolumn{9}{|c|}{ Format $4 \times 4 \times 16 \mathrm{~cm}$} \\
\hline Data & & CE2.9 & BA1.9 & SP1.9 & $\mathrm{CO} 2.9$ & MO2.9 & SV1.9 & STR \\
\hline $\begin{array}{l}\text { Sample } \\
\text { Length }\end{array}$ & (m) & 0,16 & 0,16 & 0,16 & 0,16 & 0,16 & 0,16 & 0,16 \\
\hline $\begin{array}{c}\text { Flight } \\
\text { Time } \\
\end{array}$ & $(\mu \mathrm{s})$ & 144,13 & 150,79 & 120,13 & 141,80 & 124,51 & 139,89 & 157,34 \\
\hline $\mathrm{vm}$ & $(\mathrm{m} / \mathrm{s})$ & 1110,08 & 1061,09 & 1331,8 & 1128,35 & 1285,03 & 1143,76 & 1016,88 \\
\hline pm & $(\mathrm{kg} / \mathrm{m} 3)$ & 1571,86 & 1372,87 & 1547,5 & 1497,07 & 1551,15 & 1637,52 & 1641,84 \\
\hline $\begin{array}{c}\mathrm{DE} \\
\text { Modulus }\end{array}$ & (Mpa) & 1936,98 & 1545,72 & 2745,08 & 1906,03 & 2561,40 & 2142,20 & 1697,73 \\
\hline & \multicolumn{8}{|c|}{ Format $3 \times 3 \times 16 \mathrm{~cm}$} \\
\hline Data & & CE2.9 & BA1.9 & SP1.9 & $\mathrm{CO} 2.9$ & MO2.9 & SV1.9 & STR \\
\hline $\begin{array}{l}\text { Sample } \\
\text { Length }\end{array}$ & (m) & 0,3 & 0,3 & 0,3 & 0,3 & 0,3 & 0,3 & 0,3 \\
\hline $\begin{array}{c}\text { Flight } \\
\text { Time } \\
\end{array}$ & $(\mu \mathrm{s})$ & 269,26 & 307,12 & 266,53 & 269,09 & 250,83 & 235,73 & 276,44 \\
\hline $\mathrm{vm}$ & $(\mathrm{m} / \mathrm{s})$ & 1114,18 & 976,81 & 1125,5 & 1114,87 & 1196,01 & 1272,62 & 1085,21 \\
\hline$\rho \mathrm{m}$ & $(\mathrm{kg} / \mathrm{m} 3)$ & 1635,35 & 1350,81 & 1526,2 & 1488,65 & 1584,71 & 1665,38 & 1639,66 \\
\hline DEM & (Mpa) & 2030,12 & 1288,88 & 1933,53 & 1850,30 & 2266,84 & 2697,20 & 1931,00 \\
\hline
\end{tabular}

Table 6. Dynamic modulus of elasticity comparison, (where vm is the average propagation speed $(\mathrm{m} / \mathrm{s}), \rho \mathrm{m}$ is the average density of the formulation $(\mathrm{kg} / \mathrm{m} 3)$. Produced by the authors.
A Spectrophotometry test (UNI EN ISO 15886, 2010) was performed, with the aim of comparing the colour variation of stabilized earth-based mortars with earth-sand mixture one, and assuring minor differences, as shown in table 7 .

\begin{tabular}{|c|c|c|c|c|c|c|c|}
\hline \multirow{2}{*}{$\begin{array}{c}\text { Mortar } \\
\text { code }\end{array}$} & \multicolumn{3}{|c|}{ Media } & \multicolumn{3}{c|}{$\begin{array}{c}\text { Standard deviation } \\
\text { from mortar STR }\end{array}$} & $\begin{array}{c}\text { Code } \\
\text { CIEL*a*b* }\end{array}$ \\
\cline { 2 - 8 } & $\mathrm{L}^{*}$ & $\mathrm{a}^{*}$ & $\mathrm{~b}^{*}$ & $\Delta \mathrm{L}^{*}$ & $\Delta \mathrm{a}^{*}$ & $\Delta \mathrm{b}^{*}$ & $\Delta \mathrm{E}^{*}$ \\
\hline STR & 79,75 & 1,04 & 9,89 & 0,00 & 0,00 & 0,00 & 0,00 \\
\hline CE2.9 & 64,80 & 8,77 & 22,86 & 14,95 & $-7,73$ & 12,97 & 21,24 \\
\hline BA.19 & 70,12 & 4,45 & 20,28 & 9,63 & $-3,41$ & 10,39 & 14,57 \\
\hline SP1.9 & 75,25 & 3,33 & 19,35 & 4,5 & $-2,29$ & $-9,46$ & 10,72 \\
\hline CO2.9 & 73,25 & 1,08 & 12,57 & 6,50 & $-0,03$ & $-2,67$ & 7,03 \\
\hline MO2.9 & 72,19 & 1,91 & 14,41 & 7,56 & $-0,87$ & $-4,51$ & 8,85 \\
\hline SV1.9 & 72,84 & 1,74 & 15,51 & 6,91 & $-0,70$ & $-5,61$ & 8,93 \\
\hline
\end{tabular}

Table 7. Spectrophotometry: comparison between earth mortars and STR mortar. $\mathrm{L}^{*}$ : Brightness indicator, $\mathrm{a}^{*}$ : red and green axis colour indicator, $b^{*}$ : yellow-blue axis colour indicator. Produced by the authors.

CIEL*a*b* code evaluates colour variation; a 5 CIEL*a*b* code value represents the minimum perceivable value to the naked eye (UNI EN ISO 15586, 2010). Mortars by brown soil (CO2.9, MO2.9, SV1.9) proved to produce lower CIEL*a*b* CODE values, compared to red soils ones (CE2.9, BA1.9, SP1.9); the colour variation showed, tend to result more similar to STR mortars, possibly due to the consistent amount of sand added to the mixtures, to decrease their clay content. A further test was carried out, to evaluate the use of produced mortars for restoration purposes. Stabilized earth-based mortars colour variation was compared with the colour variation of plaster samples from historical buildings in Roero area. In table 8, a traditional plaster sample, taken at Ceresole d'Alba, and plaster CE2, made with a soil from the same area, are compared. The test results show that the analysed samples have similar colorimetric characteristics, with a variation of colour visible to the naked eye, with consequent compatible and distinguishable mortars; therefore, the CE2 mortar has proven to be particularly suitable for restoration purposes.

In other cases, such as samples BA1.9 and MO2.9, mortars produced have shown a value of 2.58 and $1.90 \Delta \mathrm{E} *$, if respectively compared to the traditional plaster locally sampled, meaning that:

- the colour variation is approximately indistinguishable, then the use in restoration field requests an adequate critical interpretation,

- every case-study is singular and the optimum result in formulation and mixing is obtained preparing a right number of samples.

\begin{tabular}{|c|c|c|c|c|c|c|c|}
\hline \multirow{2}{*}{$\begin{array}{c}\text { Mortar } \\
\text { CE2.9 }\end{array}$} & \multicolumn{3}{|c|}{ Average measures } & \multicolumn{2}{c|}{ Standard deviation } & $\begin{array}{c}\text { Code } \\
\text { CIEL*a** }\end{array}$ \\
\cline { 2 - 8 } & $\mathrm{L}^{*}$ & $\mathrm{a}^{*}$ & $\mathrm{~b}^{*}$ & $\Delta \mathrm{L}^{*}$ & $\Delta \mathrm{a}^{*}$ & $\Delta \mathrm{b}^{*}$ & $\Delta \mathrm{E}^{*}$ \\
\hline Pr.1 & 66,60 & 8,24 & 19,38 & 1,73 & 0,68 & 3,87 & 4,29 \\
\hline Pr.2 & 68,24 & 8,43 & 20,17 & 4,04 & 0,15 & 2,08 & 4,54 \\
\hline Pr.3 & 68,51 & 8,50 & 19,96 & 4,10 & 0,84 & 3,79 & 5,65 \\
\hline Pr.4 & 70,30 & 7,46 & 18,87 & 5,58 & 1,3 & 3,85 & 6,90 \\
\hline Pr.5 & 70,40 & 7,20 & 18,52 & 4,86 & 1,51 & 4,17 & 6,58 \\
\hline Pr.6 & 69,37 & 8,52 & 20,65 & 4,14 & $-0,03$ & 1,71 & 4,48 \\
\hline Pr.7 & 66,11 & 7,95 & 19,25 & 1,26 & 1,02 & 3,60 & 3,95 \\
\hline Pr.8 & 69,02 & 8,51 & 20,08 & 4,04 & $-0,08$ & 2,23 & 4,62 \\
\hline Pr.9 & 69,61 & 7,94 & 19,68 & 5,49 & 0,99 & 4,06 & 6,90 \\
\hline Pr.10 & 70,50 & 7,73 & 19,28 & 5,39 & 0,89 & 3,44 & 6,45 \\
\hline Tot. & 68,86 & 8,05 & 19,58 & 4,06 & 0,73 & 3,28 & $\underline{5,44}$ \\
\hline
\end{tabular}

Table 8. CE2.9 Standard deviation from sample taken at Ceresole d'Alba. Produced by the authors. 
Compressive and flexural strength tests (UNI EN 1015-11, 2007; UNI CEN ISO/TS 17892-7, 2005) results, performed on three samples for each type of mortar, are shown in table 8 . Even if earth-based mortars show both low compressive and bending strength, if compared with STR mortar, all of them, except mortar SP1.9, accomplish with EN 1015-11(1999) compressive strength standards, as shown in Faria et al. (2014), while all mortars flexural strength doesn't reach the $0,3 \mathrm{MPa}$ required minimum standard and needs to be improved.

\begin{tabular}{|c|c|c|c|c|}
\hline \multirow{2}{*}{ Mortar code } & \multicolumn{2}{|c|}{ Compressive strength } & \multicolumn{2}{c|}{ Flexural strength } \\
\cline { 2 - 5 } & Fmax & $\mathrm{R}_{\mathrm{C}}$ & Fmac & $\mathrm{R}_{\mathrm{F}}$ \\
\hline & $\mathrm{N}$ & $\mathrm{Mpa}$ & $\mathrm{N}$ & $\mathrm{Mpa}$ \\
\hline CE2.9 & 1746,67 & 1,09 & 65,00 & 0,15 \\
\hline BA1.9 & 1616,67 & 1,01 & 55,00 & 0,13 \\
\hline SP1.9 & 1133,33 & 0,71 & 53,33 & 0,13 \\
\hline CO2.9 & 1900,00 & 1,19 & 53,33 & 0,13 \\
\hline MO2.9 & 1630,00 & 1,02 & 66,67 & 0,16 \\
\hline SV1.9 & 1743,33 & 1,09 & 63,33 & 0,15 \\
\hline STR & 2173,33 & 1,36 & 53,33 & 0,13 \\
\hline
\end{tabular}

Table 9. Compressive strength and flexural strength test results, produced by the authors.

\section{CONCLUSIONS}

The paper shows first steps of a research work for the production of earth-based mortars, with the aim of safeguarding the traditional built heritage and landscape. Three main phases were defined:

- the definition of a sustainable selection method of needed local raw materials,

- a method for stabilized earth-based mortars production, adapted to local soils and materials,

- the characterization of the prepared mortars, aiming at verifying their suitability for the stated purposes.

Phase 1 allowed to identify six different types of soil in the Roero region. A simplified method for their characterization has been evaluated and considered suitable for the purpose, as it shows a minimum percentage of error in the soil clay content estimation, if compared with UNI-ASTM standards.

The samples analysed showed that almost all soils are very clayey; therefore, the clay content has been drastically reduced, to make the soil mixes suitable for plaster mortars. Furthermore, the opportunity to collect raw materials, in the vicinity of local construction sites, was successfully explored, in compliance with national legislation on the reduction of waste from excavation activities.

Products characterization mainly confirmed mortars suitability for traditional earth and stone buildings restoration in Roero, pointing out specific minor performances to be enhanced.

Produced mortars diffractometry test highlighted high silicon content and allowed to distinguish two main types of soils: red soils with good hematite presence and brown soils. Red soils stabilized mortars showed dynamic elastic modulus comparable with standard lime-based mortars, while brown soils resulted slightly more flexible. Measured dynamic elastic modulus of both soils types resulted, anyway, quite low, though comparable with available literature data on earth-based mortars. Mortars with low elasticity modulus are considered, in certain cases, recommendable for earth walls (Gomes et al., 2016), while ensuring needed permeability to water vapour.
Almost all mortars produced have compressive strength values in line with those of European standards; even if the bending strength was found to meet the required standards, further research is recommended, to enhance it.

Colorimetric analysis showed perceivable difference with standard lime-sand based mortars, while a comparison with sampled traditional plasters, from local historical buildings, produced no visible colorimetric variation, proving the suitability of produced mortars, for restoration and maintenance interventions.

The formulated mortars can have their main application as plasters for restorations, according to a sustainable, standardised and low environmental impact process. The research approach could be a reference for the definition of conscious intervention strategies, for the requalification processes currently affecting the small villages of Roero, mainly built with earth bricks and often still preserving traditional earth-based mortars. Moreover, it could represent a supporting tool for the development of colour plans, that municipalities are now addressing, suggesting the recovery of colour tones from local landscape, aiming at the homogeneity of hamlets colours.

\section{ACKNOWLEDGEMENTS}

The Authors thanks the Company F.lli Sartore s.r.l. and Enocontrol Laboratory (Alba, CN) for their support.

\section{REFERENCES}

Accigliaro, W., 2009: Roero. Repertorio artistico: materiali sulle architetture e le opere d'arte dall'Alto Medioevo all'Ottocento. Ecomuseo delle Rocche del Roero; Astisio, Associazione artisticoculturale del Roero, Montà $(\mathrm{CN})$.

Achenza, M., Sanna, U., 2009. Il manuale tematico della terra cruda, Caratteri tecnologie buone pratiche. DEI, Tipografia del Genio Civile, Roma.

Boano, G., Molino, B., Solfetti, U., 1992. L'ambiente del Roero: caratteri geomorfologici, storici, naturalistici. Verderoero, Torino.

Briccoli Bati S., 2010, I limiti della terra come materiale da costruzione, in scritti sulla terra, il Prato casa editrice, $\mathrm{n}^{\circ} 4 / 10$ Didattica e ricerca, Saonara.

Contreras, F.U., Guerrero Baca, L.F., 2007. The use of lime in the conservation of earth construction, in proceedings of Fourth International Adobe Conference of the Adobe Association of the Southwest, New Mexico.

El Ghazzali, N., 2015. Architettura in terra cruda in Marocco, sperimentazione di Intonaci per la protezione dei paramenti murari. Tesi di Laurea, Rel. Mattone M., Politecnico di Torino.

Faria, P., Silva, V., Jamú, N., Dias, I. \& Gomes, I. 2013. Evaluation of air lime and clayish earth mortars for earthen wall renders. In M. Correia, G. Carlos, S. Rocha (eds), Vernacular Heritage and Earthen Architecture: Contributions for Sustainable Development: 407-413, CIAV2013, Vila Nova de Cerveirs, Portugal, Oct. 2013. Taylor \& Francis, London.

Faria, P., Santos, T., Silva, V., 2014. Earth-based mortars for masonry plastering. In Proceedings of the $9^{\text {th }}$ International Masonry Conference. Universidade do Minho, Escola de Engenharia, Guimarães. 
Giuria, G., 2018. Intonaci in terra stabilizzati con calce: prove sperimentali, Tesi di Laurea, rel. Mattone M., Correl. Invernizzi S., Frattini F., Rescic S., Politecnico di Torino.

Gomes, M.I., Gonçalves, T.D., Faria, P., 2016. Characterization of earth-based mortars for rammed earth repair. In Earth construction \& tradition, vol. 1, ed. Feiglstorfer H., pp. 259-275. IVA-ICRA, Institute for Comparative Research in Architecture, Vienna.

Harmard, E., Morel, J.C., Salgado, F., Marcom, A., Meunier, N., 2011. A procedure to assess the suitability of plaster to protect vernacular earthen architecture, Journal of Cultural Heritage, 14(2):109-115. Elsevier.

Houben, H., Guillaud, H., 1994. Earth Construction: a Comprehensive Guide. Intermediate Technology Publications.

Marchiano, R., Cavallo, R. (a cura di), 2019. Guida al recupero dell'architettura tradizionale e del paesaggio rurale del G.A.L. Langhe Roero Leader. G.A.L. Langhe Roero Leader.

Melià, P., Ruggieri, G., Sabbadini, S., Dotelli, G., 2013. Environmental impacts of natural and conventional building materials: a case study on earth plasters, Journal of Cleaner Production, 80: 179-186. Elsevier.

Minke, G., 2000. Earth Construction Handbook, The building Material Earth in Modern Architecture. WIT Press, Southampton.

Molino, B., 1997. Tra cielo e terra: $i$ colori dell'abitare a Montà: il piano colore del Comune di Montà. Comune di Montà, Montà $(\mathrm{CN})$.

Pennacchio, R., 2015. Tecnologie per il recupero di costruzioni in terra battuta in Piemonte, Tesi di Dottorato, rel. Bosia D. Politecnico di Torino.

Pecchioni, E., Frattini, F., Cantisani, E., 2008. Le malte antiche e moderne, tra tradizione ed innovazione. Pàtron Editore.

Quaglia, G., Lombardi, E., Revelli, F., Baldini, U., Miglio, A., 2005. Piano Territoriale Provinciale. Titolo II L.R. 56/77 e successive modificazioni - Art. 19 D. Lgs 267/00. Regione Piemonte, Cuneo.

Scarzella, P., Zerbinatti, M., 2010. Superfici murarie dell'edilizia storica: conservazione e manutenzione. Alinea, Firenze.

Scudo G., Narci B., Talamo C., 2001, Costruire con la terra, Esselibri, Napoli.

Soletti, U., 1984. Atlante storico, in Roero: Repertorio degli edifici religiosi e civili di interesse storico esistenti e scomparsi, degli insediamenti, dei siti, delle testimonianze archeologiche, a cura di Molino B., Soletti U., Vezza d'Alba (CN).

Soletti, E., Accigliaro, W., Adriano, A., Bertello, L., Martinelli, M., Molino, B., Ricciardi, G.M., Soletti, U., 1997. Roero: viaggio in una terra ritrovata. Imago, Baldissero d'Alba.

Vancetti, R., Nelva, R., 2010. Valutazione e confronto sperimentale dei moduli elastici di malte per restauro. In P. Scarzella, M. Zerbinatti, Superfici murarie dell'edilizia storica. Conservazione e manutenzione, pp. 363 - 369. Alinea, Firenze.
Vecchio, F., 2019. Valutazione delle prestazioni di malte per interventi di manutenzione, conservazione, restauro. Tesi di Laurea, rel. Zerbinatti M., Politecnico di Torino.

Vignola, M. 2019, L'intonaco nel Roero, criteri di formulazione e miscelazione di malte a base di terra, Tesi di Laurea Magistrale, Rel. Bosia D., Corel. Carbonaro C., Pennacchio R., Zerbinatti M., Politecnico di Torino.

Zerbinatti, M., 1998. Sabbie, malte e intonaci nell'edilizia storica in Piemonte e in Valle d'Aosta. Tesi di dottorato, rel. Scarzella P., Politecnico di Torino.

Decreto legislativo $\mathrm{n}^{\circ} 152,2006$. "Norme in materia ambientale", G.U. $\mathrm{n}^{\circ}$ 88. Decreto Ministeriale, 13 settembre 1999. Approvazione dei "Metodi ufficiali di analisi chimica del suolo", G.U. $n^{\circ} 248$.

ASTM D422-63, 2007. Standard Test Method for Soil Particle Sizing Analysis.

CNR BU 65/78, 1978. Determination of the porosity of aggregate granules, percentage of aggregate voids, index of aggregate voids.

COM 231, 22 settembre 2006, Strategia tematica per la protezione del suolo.

EN 1015-11:1999. Methods of test for mortar for masonry - Part 11: Determination of flexural and compressive strength of hardened mortar. CEN: Brussels 1999.

UNI EN 932-2:2000. Test methods for determining the general properties of aggregates - Methods for reducing laboratory samples.

UNI EN ISO 14688-1:2003. Surveys and geotechnical tests Identification and classification of soils - Identification and description.

UNI 11305:2009. Cultural heritage - Historical mortars Guidelines for the mineralogical-petrographic, physical and chemical characterization of mortars.

UNI EN 12504-4:2005. Tests on concrete in structures - Part 4: Determination of ultrasonic pulse propagation rate.

UNI EN ISO 15886:2010. Conservation of Cultural Heritage Test methods - Colour measurement of surfaces.

UNI EN 1015-11:2007. Test methods for masonry mate - Part 11: Determination of bending strength and compressive strength of hardened mortar.

UNI 11201:2007. Tests on fresh concrete - Determination of water content.

UNI CEN ISO/TS 17892-7:2005. Surveys and geotechnical tests Laboratory testing of soils - Part 7: Unconfined compression test on fine-grained soils.

UNI EN 933-1:2012, Tests for determining the geometric characteristics of aggregates - Part 1: Determination of grain size distribution - Grain size analysis by sieving

Decreto Ministeriale, 13 settembre 1999, Approvazione dei "Metodi ufficiali di analisi chimica del suolo", G.U. $n^{\circ} 248$ 